\title{
This Research does not Influence Policy
}

\author{
Patta Scott-Villiers
}

\begin{abstract}
This article concerns a study whose questions, methods and analytical conclusions were the work of a group of Karimojong in Uganda. Its report included text and photographs, plain language, direct voices and faces, and little theorising. When it was disseminated it appealed to local people and to a development consultant concerned with inclusion, but was dismissed as useless by a donor concerned with influencing government policy. This article looks beyond social discrimination and power in understanding these reactions, and explores the communicative encounter itself, asking what makes work relevant, meaningful and influential? This research doesn't influence policy, but it does influence local action and the work of reflective intermediaries which, after all, is important.
\end{abstract}

\section{Introduction}

We need to change our own minds before we try to change the sequence. We need to live with our energy, not by our reason. Look, this the last day of my discontented season! No more will I tolerate this greed - it's demeaning. We're needing a breeze for the stifling heat of elitist descriptions of what we can reach. But they want you to fear it, to not get too near it, so they can continue pretending they're smarter (Tempest 2011).

I want to explore some aspects of research communication, asking who is influenced and why? I begin to explore these questions by looking at a case of participatory action research in the Karamoja sub-region of Uganda, a study of young people's struggle for livelihood. I am using the case in the sense used by historian Carlo Ginzberg: not as a means of illustrating a universal point, but as an anomalous case that provokes thought (Ginzburg 2012). The young people's research has, to my mind, the virtues of a breeze oxygenating elitist descriptions of their society. But who pays attention to this cheerful zephyr? What policy does it affect if any?

Agan Kizito, Akongo Mary Lilly, Angiroi Thomas, Emai Joyce, Logira Naputaria, Lokuda Xavier, Lokut Paul, Lolepo Lotimo, Lomongin Michael Jackson, Marczela Sire, Napokol John Gaston,
Nakong Christine and Otiang Christine were employed for two months in late 2011 by the non-governmental organisation (NGO) Restless Development to design and carry out the study in Karamoja. The work's differentness (some might say naïveté or bias, some might say truthfulness) raises a question about how unusual kinds of research can be influential. The commissioners of the work and the youth team nursed a hope that the research would influence government and donor policy, but it did not. They also hoped for an effect at home, and here they did indeed achieve one.

Thus, I consider some qualities that affect the communicative encounter between the Karimojong researchers and three constituencies: their own communities, development consultants and international aid donors. I ask to what do actors in different positions attend and on which foundations are their attention and inattention built? It is axiomatic that power, wealth, gender, race, age, localness and other powerful social classifiers will affect the communicative process. But what are the social dividers working on? I find them at work on the relevance, meaning and openness of what is said. These are aspects of interpretation that affect the power of research to make a point and stimulate action. 
I begin by describing the Karamoja study and a book that it generated, and then go on to analyse the reaction. The analysis concentrates on philosophical aspects of the encounter, from which I hope the reader will gain insight into the radical difficulty of communication.

\section{The research}

We are youth from different groups in rural and urban areas of Moroto, Napak and Nakapiripirit. Some of us have been to school and some have not (Kizito et al. 2012: 10).

In November 2011, a group of 13 young women and men from the Karamoja sub-region of northeastern Uganda, ${ }^{1}$ spent five weeks researching the economic situation of youth in two Karimojong districts (Kizito et al. 2012). The work took place at a time when a decade of violent disarmament conducted by the national army, accompanied by the loss of uncounted numbers of livestock and a spiralling decline in the economy, had begun to turn towards peace and the possibility of reconstruction (Kratli 2010:13).

At the start the young people expected to be instructed what to investigate and how to do it by the foreigners who had commissioned the research. They were surprised when we asked them if they would make their own choices as to the topic, method and analytical approach.

After a week of design supported by the external facilitators, the young people began their research work alone. They visited 16 settlements and interviewed more than 500 people, sitting, helping, talking, musing, recording and taking photos. A month later, the facilitators, of whom I was one, returned to Karamoja. We spent a week helping the group to organise voice recordings, photos and stories and lay out findings. One team member, Xavier, spoke for the rest when he explained the objective that they eventually developed in relation to the question of livelihoods: 'We went to find out what strength people have.'

At the start of the analysis, they had already ordered the material into categories that the more urbane of them had observed in NGO reports - health, gender, livelihoods and so on. Putting that to one side, we asked 'What surprised you and what seemed important?' One after the other, building each upon what the one before had said, starting a little hesitant, and then taking heart, they replied:

Lokut: The depth of the mines, the lengths of the tunnels! When I saw those people struggling in the gold mines, I thought, those people have strength and courage.

Napokol: The mines sometimes kill people. They go in naked. It's hot. Thirty people died when a tunnel collapsed.

Lily: I had not seen it with my naked eyes. Out of a heap of soil like this they found this little little gold! You have to be determined - to appreciate the little.

Agan: We met a group of youth quarrying behind the mountain. They pushed rocks down the mountain. Sometimes the rocks killed people.

Lomoying MJ: To see people staying without cows, they used to have so many. Now people earn a living through whichever ways, they don't go to school. They are just living.

Lily: To see warriors accepting peace - they have seen that if you do your own work you get things, not through the gun.

Lokut: These people are strong. They are trying to find ways of living, even if it is very hard.

When we analysed all the stories and interviews we found a common pattern of strengths in almost all of them... These strengths have been mostly ignored by those who come here from outside (Kizito et al. 2012: 45).

A month later the team had published a short book presenting evidence and argument about the strengths of Karimojong youth. Its highresolution photographs of people sweating, working, walking, smiling, sitting, thinking, frowning and laughing, flanked by cows, fields, calabashes, gold mines, piles of gravel and stones, rutted roads, grain stores, beer, beads, rats, hats and houses gave evidence for their findings. The bright greens showed the return of rain after years of drought. The textures of grit and mud showed the struggles of making a living in mines, gravel pits and fields after the loss of all their wealth. And the patterned reds, oranges and purples of clothes and jewellery showed the 
assertive arrangements of Karimojong identity: age, gender and culture. The book positions itself as a work that can 'unite the people.' It argues for a policy of strengthening what people are already doing to resolve difficulties, even where this is against a government policy of sedentarisation. Copies are now in each of the 16 settlements, as well as scattered about NGO and local government offices and further afield.

The narrative structure takes the reader on a journey from settlement to settlement across the topography, society and economy of the two districts. It introduces people in their places. The diverse interlocutors speak empirically in the first person of their own lives and livelihoods. The journey links their different voices together in a geographical context and the names and faces give the words authority in its most literal sense. The truth, or otherwise, and utility of the words is grounded in topics, people and places.

The final section draws out the patterns in the material and generates an argument. It is directed to local appreciation and action, but also to those who do not, or would rather not, see the Karimojong as strong. I found the presentation refreshing - I had read and heard so many doomladen opinions about Karamoja that I had begun to believe the people must all be depressed and desperate. Not at all. The youth criticise NGO and government officials for misreading them:

We feel that people who come from the outside think that they know more about Karamoja than those who live here. Using only what they have read in books, they do not want to be challenged and they want to eat alone (Kizito et al. 2012: 13).

The authors end by emphasising, 'We Karimojong have our culture. It cannot be detached from us.' This final pair of sentences is significant. It is directed at those who aim to change Karimojong to some other kind of people, servile and sedentary. Given the scale of recent oppressions in the subregion, this is a brave thing to say. It is a call of leaders to their people, and a call of citizens to policymakers. Did either call have any effect?

\section{Reactions}

Here I will focus on three individuals to exemplify a range of reactions to the book: a local youth, a development consultant, and an official of an international development agency. The youth was encouraged, the consultant enthusiastic and the official dismissive.

\section{$A$ young man}

Unlike much of development research, the study we are considering invites local people into debate. Napokol, one of the researchers, told me of the reaction of one young man who met the team when they returned to the settlements in January 2012 to bring the book to the people.

The written language, English, was not comprehensible, but the photos were clear. And in conversation with Napokol, Agan, Joyce, Naputaria and the rest, the young man and others reconstructed and discussed the messages. Then the young man said, 'We can use this research to tell people in other villages that we should pay attention to those of us who are strong. We can tell them to be like the strong ones.' This idea was repeated by several others. It was an effect.

This was a Karimojong study of the Karimojong lifeworld. The lifeworld, as Habermas (1984) elaborates, is the world in which we live, in which the things that impinge on us are simultaneously the things that constitute us. As such, research into the lifeworld is concerned with belonging. Lifeworld research, if done well, may be particularly comprehensible, and thus potentially relevant, to those who belong strongly to the same or a similar lifeworld, who have similar constructions of meaning and understanding, and a shared presence. Importantly, the interlocutor also needs to have a question that is provoked into life by the argument. In Karamoja, arguments about strength and struggle are part of an urgent conversation going on at multiple levels of society. Thus the first explanation for the youth's positive response is one of relevance. The book offers him a recognisable and interesting line of reasoning.

A second philosophical explanation for his positive response relates to appreciation of the meaning of that which was not said. Every statement has an unsaid side, a universe that resides in the words and in their effective history (Gadamer 1993: 302). The unsaid is an inseparable part of the proposition, it is what 'hopes to be heard in our sentences' (Grondin 1995: 13). The communication brings this hinterland forward, but much of it is only available for inference. The 
effective history of the words comes into encounter with an equivalent hinterland brought by the listener. The auditor participates in that history as she or he tries to make coherent and understand the meaning of what is said. This unsaid aspect of communication is at work in research from its elaboration through its questions to its pronouncements. For example, the question 'what are our strengths?' arose from the young people's experience of history. The question's meaning has resonance to them, bringing forward the struggles of disarmament, the confusions of their changing roles in society, cultural understandings of youth and so on. Life and strength today stands in contrast to a prior (perhaps mythical) life and strength once lived by young Karimojong. The young man who saw and heard all this in the study's question recognised it at once, and liked it. It articulated his own hinterland.

What surprised (and pleased) the young man was how widespread were the sentiments about strength. It opened the possibility that this sentiment should be discussed further. It gave him an ambition to use the research for an action of solidarity. This is the third aspect of the research success - its openness to a future.

It is reasonable to suggest that the young man also appreciated the research method, giving it validity to his mind. The method is phenomenological, a mode of practical attentiveness (Sokolowski 2000:4) in which the focus is on concrete things as they appear to a variety of observers or from a range of perspectives. Such an approach to research is commonly practised by pastoralist people in East Africa, and the Karimojong have a similar epistemology (Scott-Villiers 2009). The text includes no hearsay, nor overt theory, nor speculation. It is has short sentences with few adjectives and adverbs. The spareness of the sentences and the repetition of points by multiple speakers give a sense of truthfulness. I notice this, because it is in contrast to my own way of embellishing the concrete with imaginaries, frames of analysis and attempts at social theories. In pastoralist societies in East Africa there is a high premium on concrete clarity and accuracy.

Barely theorised talk also has an open quality to it. Further perspectives could be added. The communication does not wrap the matter up, rather it says, 'This is what these topics look like so far'. It offers the reader the possibility of making a contribution to a continuing conversation about what is happening and what it means. It invites engagement.

\section{A consultant}

We move on now to a second interlocutor and ask if these same three elements, relevance, recognition and openness, were present. A few weeks after the book had been published, a friend of mine sent me an email. She is a consultant in international development.

Dear Patta

Jess sent me the report that you were involved in in Karamoja. I just wanted to say 'Thank you' - it was a real treat to read on a cold, dark snowy evening. I just love the colours, the pace, the energy that just jumps off the page, the positive language, the positive twist on the analysis, the 'we', the very powerful conclusion, it wasn't about disarmament but boy does the point just jump out. In fact the whole book just jumps out. A really great achievement. Hopefully Restless Development will be able to continue with follow up, always the tough question isn't it?...

Very best wishes

Leslie

Dr Leslie Groves Williams

Independent Social Development Consultant

Leslie edited a book with Rachel Hinton called Inclusive Aid (Hinton and Groves 2001). Her work and her questions originate in a concern for inclusion of people who are oppressed and marginalised. She seeks to enrich technical aid and development solutions with understandings of how society embraces its diverse members and how aid programmes can facilitate inclusion. As she puts it, 'I describe my work as trying modestly to mediate between different voices, with emphasis of course on getting local voice/voice of least powerful into policy, but also the other way too' (pers. comm.). Her 'of course,' indicates that inclusion is, or has become, part of her lifeworld. The inclusion of young people in the realm of those capable of doing useful research would thus be relevant to her.

Her background, though profoundly different from that of the Karimojong, gives their arguments meaning to her. Their point about not 
being listened to by officials is aligned with her question about inclusion, and their conclusions about strength provoke her thought. Their open dialogical approach is appealing to her, because in her position as a consultant in the development realm she does not want the certainty that is needed for a policy. She needs ideas that help her act as a mediator between people and policy. She needs to know both worlds so that she can do her work as an artful teacher in development organisations. She reads the research with a respect for the possibilities of inspiration and action.

\section{A policymaker}

A member of a bilateral donor organisation offers the third reaction. In her job she needs policy material to furnish her arguments with evidence and theoretical frames when she engages with government policymakers. She also needs it with colleagues, to guide investments. She said to me, 'There is nothing in this book that I don't already know. It's very attractive to look at, but I can't use it. When I'm dealing at the policy table I need something that works on a technical and political level.' I pointed out that I had read no reports on Karamoja that focused on the strength rather than the weaknesses of the place and people. 'It is naïve to call those people strong,' she replied. I added that the report includes an unusual critique of NGOs. She conceded on this point, but remained uninterested. 'This research does not influence policy,' she concluded. To that I conceded.

In the realm of the policymaker, the photographs, voices, phenomenological approach and lack of conclusiveness are a weakness. There is no common lifeworld, so no relevance to the efforts of those at the policy table. The words convey an unspoken meaning that shouts backward, unprofessional and unreasoned. The impression of all those pictures and all that plain English is not one of simple truth, but of simple-mindedness. The tendency of an oral culture to repeat phrases like poetry appears unskilled to those for whom the written report has its own, quite different, protocols. Historic encounters and formal research have long situated these people as poor and powerless (Kratli 2010; Scott-Villiers 2011). Donors, government and NGOs would expect Karimojong to complain from their subaltern position, yet would largely consider such criticism ill informed. It has become a class thing, with class distorting meaning (Spivak 1988). The research appears biased and of little use.

This kind of research will never easily answer a policymaker's questions, since policy is a product of governmentality, a different question to that generated within the lifeworld of the non-elites. Government policy towards Karamoja emphasises submission to alternative livelihoods and welfare systems. Phenomena of indigenous strength and culture are not in that frame. The openness of the Karimojong text to further development through dialogue suggests a technical weakness in policy terms and possibly a political threat too. The text offers no conclusive point to guide the kinds of investment that are the purview of the donor - education, social welfare, infrastructure and institutions. To Karimojong, the dialogic method, presentation and recommendation suggest solidarity. To outsiders the same might appear as a populist threat. The material appears to be rabblerousing and anecdotal. That 500 people contributed to the anecdote does not improve its validity in the eyes of the policymaker.

\section{Conclusion - the gulfs of effective history}

We are familiar with the idea that negative discrimination creates prejudice, power sets boundaries on validity, and difference generates misunderstandings. But we have spent less time considering how discrimination, power and difference are all assisted here by effective history. If people on the margins want to be heard by policymakers or academics it will require more than positive discrimination, and more than a reshaping of the social limits that define what is possible (Hayward 1998: 21). It requires a confrontation and fusion of lifeworlds: hermeneutic attention to foundational issues of relevance, meaning and truth (Gadamer 1993).

We see in our example that the relevance of an argument to an interlocutor depends on its connecting to existing arguments, that its meaningfulness depends on an appreciation of a hinterland of the unsaid, and that its provocation to action depends on the hearer heeding an invitation to engage.

Audiences react in various position-dependent ways. For a policymaker, policy is relevant, her scope of meaning has little overlap with that of Karimojong, and her decisions need to make a 
claim to certainty. She is unable to act on this research. For the consultant, the study offers to add new dimension to her questions. She gives it space to speak to her and, though not having full access to its volumes of meaning, will glean something from it. Its openness to dialogue fits with her orientation towards debate rather than certainty. She is indicative of a substantial body of thought and action in development. In some ways this article is for her, in the hope it may help her (in effect, me) to see more clearly what she is working on.

In the end, it is the young man who understands most of the meaning of the research and is most

\section{Note}

1 The work was commissioned by Restless Development Uganda, funded by the United Nations Population Fund (UNFPA) and the

\section{References}

Chatterjee, P. (2004) The Politics of the Governed: Reflections on Popular Politics in Most of the World, New York: Colombia University Press

Gadamer, H.-G. (1993) Truth and Method, London: Sheed \& Ward

Ginzburg, C. (2012) Threads and Traces: True False Fictive, Berkeley: University of California

Grondin, J. (1995) Sources of Hermeneutics, New York: State University of New York Press

Habermas, J. (1984) The Theory of Communicative Action, Vol II, London: Heinemann

Hayward, C.R. (1998) 'De-Facing Power', Polity 31.1: 1-33

Hinton, R. and Groves, L. (2001) Inclusive Aid, London: Intermediate Technology Publications

Kizito, A. et al. (2012) Strength, Creativity and Livelihoods of Karimojong Youth, Brighton: Restless Development and IDS influenced. This is not because he is credulous. He finds in it an address to his own questions, its meaning is resonant and he can see a way forward. The piece of research may not influence government and donor policy immediately, but it is useful in Karamoja. The young man, who is poor and has no power with the state, has powers as part of local society. He is, like billions of others, part of the popular politics of most of the world (Chatterjee 2004). That the research is useful to him, that it provides a means by which he can, as Kate Tempest urges 'change his own mind', and thus 'change the sequence' is its strongest claim to having been worthwhile.

Department for International Development (DFID), and facilitated by Pastoralist Consultants International and the Institute of Development Studies, including myself.

Kratli, S. (2010) 'Karamoja with the Rest of "the Rest of Uganda"', Nomadic Peoples 14.2: 3-23

Scott-Villiers, P. (2011) “"We are not Poor!" Dominant and Subaltern Discourses of Pastoralist Development in the Horn of Africa', Journal of International Development 23: $771-81$

Scott-Villiers, P. (2009) 'A Question of Understanding: Hermeneutics and the Play of History, Distance and Dialogue in Development Practice in East Africa', thesis, University of Bath

Sokolowski, R. (2000) Introduction to Phenomenology, Cambridge: Cambridge University Press

Spivak, G.C. (1988) 'Can the Subaltern Speak?', in C. Nelson and L. Grossberg, Marxism and the Interpretation of Culture, London: Macmillan

Tempest, K. (2011) 'What we Came After', Sound and Fury, http://vimeo.com/28884746 (accessed 29 June 2012) 